\title{
Alternative Methods of Collective Disputes Resolution in the Czech Republic ${ }^{1}$
}

\author{
Klára Hamul'áková \\ Jana Petrov Křiváčková \\ Department of Private Law and and Civil Procedure, \\ Faculty of Law, Palacký University Olomouc \\ tr. 17. listopadu 8, \\ Olomouc 771 11, Czech Republic \\ E-mail: klara.hamulakova@upol.cz \\ E-mail: jana.petrov@upol.cz
}

Abstract: On 11 June 2013, the Commission issued the Recommendation on common principles for injunctive and compensatory collective redress mechanisms in the Member States concerning the violations of rights granted under Union law. The main areas where private enforcement of rights granted under Union law in the form of collective redress is of value are consumer protection, competition, environment protection, protection of personal data, financial services legislation and protection of investments. Point 13 of the Recommendation concurrently emphasises that the principles it puts forward relate both to judicial and out-of-court collective redress. The Member States should ensure that judicial collective redress mechanisms are accompanied by appropriate means of collective alternative dispute resolution available to the parties before and throughout the litigation. Point 25 et seq. of the Recommendation then contains special regulations concerning collective alternative dispute resolution and settlements. The purpose of this article is to evaluate if the current legislation on alternative dispute resolution in the Czech Republic meets the principles encompassed in the Recommendation or if radical legal changes need to be adopted.

Keywords: alternatives, collective disputes, collective redress, Czech Republic, methods

This article was supported by the Czech Science Foundation Project 'Collective Redress in the Czech Republic-Present Situation and Perspectives' (GA16-06065S). 


\section{Introduction}

On 11 June 2013, the Commission issued the Recommendation on common principles for injunctive and compensatory collective redress mechanisms in the Member States concerning the violations of rights granted under Union law (EC, 2013b; hereinafter referred to as the Recommendation). ${ }^{2}$ The Recommendation contains the common principles for injunctive and compensatory collective redress mechanisms and the specific principles for compensatory collective redress mechanisms as well. ${ }^{3}$

The principles stated in the Recommendation will apply in all areas where the private enforcement of collective claims for injunctive and compensatory collective redress mechanisms granted under Union law is of value (point 7 of the Recommendation). The principles set out in this Recommendation should be applied horizontally. The main areas where private enforcement of rights granted under Union law in the form of collective redress is of value are consumer protection, competition, environment protection, protection of personal data, financial services legislation and protection of investments.

Prior to issuing the Recommendation, a study on the functioning of collective redress mechanisms in individual Member States was conducted, and it was found that the individual Member States vary in the extent of collective redress and that the proceedings often differ (European Commission - DG Sanco, 2008). The aim of this Recommendation is to facilitate access to justice in relation to

2 The Recommendation does not cover existing branch complaints of omission legislated by Union law. Within the framework of the EU, collective redress was described in various degrees in the following documents: Commission Green Paper on damages actions for breach of the EC antitrust rules (EC, 2005); Commission White Paper on damages actions for breach of the EC antitrust rules (EC, 2008b); Commission Green Paper on Consumer Collective Redress (EC, 2008a); Regulation of the European Parliament and of the Council 2006/2004 on consumer protection cooperation (EC, 2004), Directive of the European Parliament and of the Council 2009/22/EC (EC, 2009) on injunctions for the protection of consumers' interests. These documents focus on the area of consumers' protection and antitrust rules. The following documents touch upon collective redress on a more general level: Commission Public Consultation 'Towards a Coherent European Approach to Collective Redress' (EC, 2011); Commission Communication 'Towards a European Horizontal Framework for Collective Redress' (EC, 2013a).

3 The compensation awarded to natural or legal persons harmed in a mass harm situation should not exceed the compensation that would have been awarded if the claim had been pursued by means of individual actions. In particular, punitive damages, leading to overcompensation in favour of the claimant party of the damage suffered, should be prohibited (point 31 of the Recommendation). 
violations of rights under Union law and to that end to recommend that all Member States should have collective redress systems at national level that follow the same basic principles throughout the Union, taking into account the legal traditions of the Member States and safeguarding against abuse.

The Member States should carry out the Recommendation by 26 July 2015. In addition, the Member States should collect reliable annual statistics on the number of out-of-court and judicial collective redress procedures and information about the parties, the subject matter and outcome of the cases. They should communicate the information collected to the Commission for the first time by 26 July 2016 at the latest. The Commission should assess the implementation of the Recommendation on the basis of practical experience by 26 July 2017 at the latest. In this context, the Commission should in particular evaluate its impact on access to justice, on the right to obtain compensation, on the need to prevent abusive litigation and on the functioning of the single market, on SMEs (small and medium-sized enterprises), the competitiveness of the economy of the European Union and consumer trust. The Commission should assess also whether further measures to consolidate and strengthen the horizontal approach reflected in the Recommendation should be proposed.

Point 13 of the Recommendation concurrently emphasises that the principles it puts forward relate both to judicial and out-of-court collective redress. The Member States should ensure that judicial collective redress mechanisms are accompanied by appropriate means of collective alternative dispute resolution available to the parties before and throughout the litigation. Application of such means should depend on the consent of the parties involved in the case (point 26 of the Recommendation).

Alternative dispute resolution is concurrently emphasised in group actions that enable them to claim compensation. Point 16 of the Recommendation states that alternative dispute resolution procedures can be an efficient way of obtaining redress in mass harm situations. They should always be available alongside, or as a voluntary element of, judicial collective redress. Point 25 et seq. then contains special regulations concerning collective alternative dispute resolution and settlements.

Collective alternative dispute resolution is at the very core of this article. Its purpose is to evaluate if the current legislation on alternative dispute resolution in the Czech Republic meets the principles encompassed in the Recommendation or if radical legal changes need to be adopted. 


\section{Basic principles of the Recommendation}

The principles encompassed in the Recommendation should also be applied in terms of collective alternative dispute resolution, the extent of their application, however, depends on the type of alternative resolution. The following are only the principles which make their application in collective alternative dispute resolution arguable.

A. The Recommendation anticipates both group and representative actions. ${ }^{4}$ In terms of group action, the opt-in model should be mostly applied. It is emphasised that regarding the compensation actions, any exception (opt-out) to this principle, by law or by court order, should be duly justified by reasons of sound administration of justice (point 21 of the Recommendation). In the case of representative action, the States should identify representative subjects that are able to take representative action, based on clearly specified capacity conditions (the subject's non-profit nature, the subject's direct relations between their main goals and the rights granted under Union law whose violation the action states, sufficient financial and personal capacity and the subject's legal expertise). The Member States are allowed to entrust this competence to the organs of public power. ${ }^{5}$

A member of the claimant party should be free to leave the claimant party at any time before the final judgement is given or the case is otherwise validly settled, subject to the same conditions that apply to withdrawal in individual actions, without being deprived of the possibility to pursue its claims in another form, if this does not undermine the sound administration of justice (point 22 of the Recommendation). Natural or legal persons claiming to have been harmed in the same mass harm situation should be able to join the claimant party at any time before the judgement is given or the case is otherwise validly settled (point 23 of the Recommendation).

$4 \quad$ Theory differentiates between two concepts of collective actions: representative and group actions. A typical feature of representative action is that the persons whose interests are the cause of the dispute are not present to the action - their court status is not defined. The outcome is not therefore binding on them, nor does it pose as an enforcement order on them. Group action authorises a wide range of persons to initiate the action and enables the group members to participate in the dispute and to achieve reparations of pecuniary claims. Concerning the member participation, two concepts of group actions: so-called opt-in and opt-out variants. Opt-in action is attended by those group members who apply for participation in the given period. Opt-out action, on the other hand, is carried out with all of the group members who do not express their will not to participate (Balarin \& Tichý, 2013, pp. 17-26).

5 In the Czech legal environment, e.g., the Ombudsman. 
B. In collective actions, the court should verify at the earliest possible stage of litigation that the conditions for collective actions (cf. Freer, 2012, pp. 779-788) are met (so-called certification, point 8 of the Recommendation).

C. The Member States should ensure that it is possible for the representative entity or for the group of claimants to disseminate information about a claimed violation of rights or mass harm situation and their intention to seek an injunction (point 10 of the Recommendation).

D. The Member States should establish a national registry of collective redress actions (point 35 of the Recommendation). The national registry should be available free of charge to any interested person through electronic means and otherwise. Websites publishing the registries should provide access to comprehensive and objective information on the available methods of obtaining compensation, including out of court methods. Thus the registry should serve to persons concerned for finding out the information needed to evaluate their potential participation in collective actions, information on the progress of the action and at the same time provide these persons with information about possibilities of their dispute resolution. The Recommendation applies the permission to view the registry only to those persons who prove their legal interest in viewing the registry. In our opinion, however, basic information on the action (parties, subject matter) should be available for the public in general.

E. The Member States should ensure that the party that loses a collective redress action reimburses the necessary legal costs borne by the winning party ('loser pays principle'), subject to the conditions provided for in the relevant national law (point 13 of the Recommendation)

F. The Member States should ensure that the lawyers' remuneration and the method by which it is calculated do not create any incentive to initiate litigation that is unnecessary from the point of view of the interest of any of the parties. The Member States should not permit contingency fees which risk creating such an incentive. The Member States that exceptionally allow for contingency fees should provide for appropriate national regulation of those fees in collective redress cases, taking into account in particular the right to full compensation of the members of the claimant party (points 29 and 30 of the Recommendation).

G. Other means to prevent abuse of mass actions is the prohibition of punitive damages (point 31 of the Recommendation) and the transparency of how the claimant party is funded (point 14 et seq., point 32 of the Recommendation). 


\section{The current state of collective redress legislation in the Czech Republic}

There is no comprehensive approach to collective redress in the Czech Republic. Legal order reflects only specific aspects of collective redress, in general in the Code of Civil Procedure (CCP) and in the special acts. ${ }^{6}$

The Code of Civil Procedure enables subjective cumulation both on the claimant and respondent party ( $\$ 91$ of CCP), but this is a universal institute of procedural law which does not show any specifications compared to the typical course of procedure. The legislation that touches upon the collective redress is that of $\S$ 83 of CCP which defines obstruction of the matter initiated, and also $\S 159 \mathrm{a}$ of $\mathrm{CCP}$ defining obstruction of the matter lawfully judged for potential actions of other persons who make the same claims from the same conduct against the same respondent.

The current legislation does not reflect requirements of the right to a fair trial of all affected persons, for they are not enabled to actively participate in the proceedings as a party of the proceedings - this being caused by the two aforementioned obstructions. Although they are allowed to join the proceedings already started by another person as an accessory party, it does not guarantee them an equal position as the actual party of the proceedings if it concerns carrying out dispositional operations in the finding procedure, submitting a motion for enforcement of judgement if the claimant party does not do so as a legitimate person ( $\$ 93$ of CCP). In addition, they are only permitted to join only on the condition that they know about the proceedings in time. In fact, the law does not obligate the court to announce the information about the proceedings initiation publicly. ${ }^{7}$

The legislation quoted makes itself possible to abuse because of its flaws, mainly by deliberate reckless management of the dispute that is beneficiary for the respondent which influences other persons involved. The verdicts issued in

6 Cf. particularly $\S 25$, Para. 2 of Consumer Protection Act (1992), § 2989 of Civil Code (2012), § 50-53 of Act on Takeover Bids (2008).

7 On the other hand, CCP enables - in matters of rights violated or threatened by conduct of unfair competition, protection of intellectual property rights and in the matters of consumers' rights protection - that the court shall be authorised in the verdict to grant the participant, whose motion was satisfied, upon the petition by that participant, the right to publish the judgement at the expense of the unsuccessful party; depending on the case circumstances, the court shall also determine the extent, form and manner of publishing $(\$ 155$, Para. 4 of CCP). This way those who wish to take action for compensation are informed about the outcome of the proceeding. 
the proceedings on omission additionally function as a binding response for the prejudicial enquiry to other proceedings on positive claims of these persons ( $\S$ 135 of $\mathrm{CCP})$.

Another drawback of the Czech legislation is that it concerns mainly the proceedings on omission of particular conduct of the respondent ${ }^{8}$, the subsequent enforcing of the compensation then takes place in separate, usually independent proceedings ${ }^{9}$ which is reasonably found ineffective and uneconomic.

\section{Mechanisms of alternative dispute resolution in the Czech Republic in light of the principles of the Recommendation}

In the Czech Republic, alternative dispute resolutions are, inter alia, a conciliation procedure, which results in a so-called praetorian settlement ( $\$ 67$ et seq. of CCP) ${ }^{10}$, arbitration (Act No. 216/1994 Coll., on arbitration and enforcement of arbitration awards) and mediation (Act No. 2002/2012 Coll., on mediation). Their application is not out of the question even in cases of mass dispute whose specifications should be taken into account by the legislation in the future.

Praetorian settlement and arbitration awards issued in arbitration are both titles for enforcement of judgements (enforcement orders). As for mediation, the parties of the mediation agreement must, if they wish to make the agreement directly enforceable, make a motion to the court which then validates this agreement as so-called praetorian settlement ( $\left(67\right.$, Para. 2 of CCP). ${ }^{11}$

\subsection{Praetorian settlement ( $\$ 67$ et seq. of CCP)}

A praetorian settlement is an agreement of the parties validated by the court resolution at the stage before the finding procedure, in the so-called conciliation procedure. Conciliation procedure is initiated by a motion only and it is fully at the parties' discretion whether they eventually come to a conciliation. Subject-

\footnotetext{
8 An exception is the right for compensation under $\S 50$ of Act on Takeover Bids (2008).

9 Joining of subject matters is not excluded (§ 112 of CCP).

10 To be distinguished from judicial settlement ( $\$ 99$ of CCP), see below for more.

11 Apart from this, it can come to out-of-court resolution by conciliation in the form of renegotiation, the final agreement can be done in the form of notarial record with permission for direct enforcement- $§ 71$ et seq. of Notarial Code (1992) - which results in obtaining a direct enforcement order. Among the means of alternative dispute resolution are also financial arbitrator, association arbitration committee, and others.
} 
matter jurisdiction for approval of the conciliation falls to any court that was otherwise authorised in the matter of judgement ( $\$ 67$, Para. 1 of CCP). If the subject-matter jurisdiction court was a regional one, the conciliation procedure and the conciliation approval can be carried out by any district court. In connection to mass dispute resolution under conciliation procedure, it would be necessary to consider leaving thusly legislated subject-matter jurisdiction, or allow the conciliation to be always debated by a district court as well. We believe that an intervention with current legislation is not needed just because of subject plurality, unless the legislator would choose causal jurisdiction for particular court/courts for mass actions in general.

More subjects can join the conciliation procedure in the position of a claimant (or other parties), similarly to typical disputable procedure without the procedure becoming collective. In the future, the motion should therefore clearly state that it is collective conciliation, or the parties can add this fact during the conciliation procedure.

The principles of the general collective finding procedure from the Recommendation are applicable in the conciliation procedure with no major difficulties. ${ }^{12}$

Apart from the praetorian settlement, there is the so-called judicial settlement ( $\S$ $99, \S 100$, Para. 1 of CCP). This cannot be understood, however, as one of the ways for alternative dispute resolution because it takes place under an alreadyinitiated finding judicial procedure. It is through a means of consensual dispute resolution. The court, under $\S 99$ of CCP seeks to resolve the dispute amicably if the nature of the dispute allows it, even in the case of preparatory meeting [ $\S$ $114 \mathrm{c}$, Para. 3, lett c) of CCP].

Therefore there will be no reason to exclude the application of the judicial settlement institute from the future legislation on collective judicial procedure.

\subsection{Mediation}

Mediation means dispute resolution process with the participation of one or more mediators who support the persons involved and help them achieve an amicable resolution by concluding a mediation agreement ( $\$ 7$ of Act No. 202/2012 Coll., on Mediation). The parties of the conflict and the conflict specification must be

12 An exception could be procedure costs when the parties of the conciliation procedure do not have the right for cost reimbursement based on its result, unless the conciliation on reimbursement states otherwise [§ 146, Para. 1, lett a) of CCP]. 
described in the agreement on the execution of the mediation ( $\S 4$, Para. 2 of the Act on Mediation).

It is apparent under the autonomy of the will that the way is clear for collective group mediation as well. Right before the conclusion of the agreement on execution of the mediation, those who consider its conclusion are in no way prevented from disseminating information about a claimed violation of rights and their intention to seek a mediator. It should be possible to enable other persons to join the agreement on execution of mediation even after its conclusion. It is left to the parties' will to decide whether they will negotiate with the person who wishes to join as a mediation party, that is, whether this person is permitted to participate. If the participants agree on a mass meeting before the mediator, the Recommendation is partially applicable, mainly because of the necessity of choosing a group representative. However, it is not possible to consider certification (the participant range is defined by the freedom of contract, not by the mediator's decision on who he/she will lead the mediation with) ${ }^{13}$, registry, and other institutes that would defy the nature of the mediation concerning its voluntary character.

The representative model could be applied under mediation when a particular representative subject would act as a deputy for the parties as a party of the agreement on the execution of the mediation - and, consequently, the mediation agreement as well — who would be authorised for that by the requirements of the Recommendation.

\subsection{Arbitration}

According to the judicature of the Constitutional and Supreme Court, arbitration is a finding procedure. Discussing the matter of arbitration does not mean giving up the legal protection but rather moving it to another deciding authority that finds law. ${ }^{14}$

For this reason as well, it is obvious that the principles of the Recommendation will be fully applicable in arbitration and that they cannot be altered by the Statutes of the permanent courts of arbitration. Active legitimation will be corresponding with the legislation stipulated for mass judicial procedures, or more precisely, it will copy the requirements of the Recommendation. Certification should be carried out by the arbitrators themselves. In case of mass

13 Defining a period comes into consideration, in which other affected subjects can join the mediation agreement.

14 CCC, 2011; CSC, 2012. Both courts support the so-called jurisdiction theory. 
consumers' dispute, the arbitrator will have to be a person registered in the registry of arbitrators under the Ministry of Justice, as it is stated in $\S 4$, Para. 3 of the Act No. 216/1994 Coll., on Arbitration in individual consumers' disputes. In our opinion, the person of the arbitrator should not be required to fulfil other demands than those in the current legislation in other cases.

Concerning the obligation of information, this could conflict with $\S 19$, Para. 3 of the Act on Arbitration, according to which the proceedings are always nonpublic. Non-publicity is related particularly to the person of the arbitrator who is legally obliged to remain silent ( $\S 6$ of the Act on Arbitration) and furthermore related to the proceedings which are not made public. On the other hand, nonpublicity cannot be perceived as the absence of information on the arbitration taking place, the identity of the parties and their legal representatives and the assembly of the arbitration senate (Bělohlávek, 2012, p. 698). This information as well should be available to the public in the registry. Contrary to the judicial procedure on collective actions, the confidentiality of information will be more emphasised in arbitration with regard to its nature. The affected persons will be able to contact the parties of the dispute based on the publicly available information, or alternatively, their representatives or group representatives and arbitrators. The next course of action will depend on their individual interaction. The arbitral award can be annulled under legally defined conditions ( $\$ 31$ of the Act on Arbitration). In connection to consumer disputes, the Act on Arbitration makes it possible to annul the arbitral award if the arbitrator of the permanent court of arbitration ruled on a consumer agreement against the legal regulation established for consumer protection, or in obvious contradiction with good manners or public order [ $\S 31$, Para. 1, lett g) of the Act on Arbitration]. Another similar option to consider is the introduction of annulling the arbitral award if the award was issued in the collective dispute against the legal regulation that defines the minimal standard (prohibition of the penalty function of compensation, definition of representation award, procedural cost reimbursement) of requirements for mass action procedure. The addition of this reason to special options for making the motion for stopping the enforcement of a judgement, defined in $\S 35$ of the Act on Arbitration, could be considered in the same way. 


\section{Encouragement}

The Member States should ensure that the parties to a dispute in a mass harm situation are encouraged to settle the dispute about compensation consensually or out-of-court, both at the pre-trial stage and during the civil trial (point 25 of the Recommendation), taking also into account the requirements of Directive 2008/52/EC of the European Parliament and of the Council of 21 May 2008 on certain aspects of mediation in civil and commercial matters (hereinafter referred to as the Directive). ${ }^{15}$

The mediation provided in this Directive should be a voluntary process in the sense that the parties are themselves in charge of the process and may organise it as they wish and terminate it at any time. However, it should be possible under national law for the courts to set periods for the mediation process. Moreover, the courts should be able to draw the parties' attention to the possibility of mediation whenever this is appropriate (point 13 of the Directive).

Nothing in this Directive should prejudice national legislation making the use of mediation compulsory or subject to incentives or sanctions provided that such legislation does not prevent parties from exercising their right of access to the judicial system. Nor should anything in this Directive prejudice existing selfregulating mediation systems in so far as these deal with aspects which are not covered by this Directive (point 14 of the Directive).

The Directive therefore enables the law to obligatorily stipulate the application of mediation means. However, the right to access the courts cannot be taken away by this.

It is thusly ruled out that the previous application of mediation would create a condition to approach the court, but at the same time it is possible for the court to oblige the parties to participate in mediation under the judicial procedure. In the event of failure, it must naturally continue in judicial procedure and decide the case. ${ }^{16}$ Which means that points 25 and 26 of the Recommendation can be interpreted this way as well, not only with respect to mediation but also to other alternative forms of dispute resolution.

The current legislation under $\S 100$, Para. 1 and $\S 114 \mathrm{c}$ of CCP is in accordance

15 Directive of the European Parliament and of the Council 2008/52/EC on certain aspects of mediation in civil and commercial matters.

16 Not participating in this mediation can influence the award of cost reimbursement (cf. $\S 150$ of CCP). 
with the aforementioned requirements for mediation and settlement. Once the proceedings were initiated, the court proceeds without other proposals, so that the matter is discussed and decided on as soon as possible. It seeks to ensure that the dispute was resolved amicably ( $\$ 100$, Para. 1 of CCP). If practical and appropriate, the president of the senate may order the parties to meet with a registered mediator for the first time in the extent of three hours and adjourn the proceedings, but for no longer than three months. If the parties do not settle on a mediator without undue delay, he/she is selected by the president of the senate from the registry under the Ministry. The proceedings continue after the three-month period. The first meeting may not be required to take place while the provisional measure in matters of protection against domestic violence is in effect ( $\$ 100$, Para. 2 of CCP).

Should the court order a preparatory meeting, here it also seeks to ensure that the dispute was resolved amicably, or it can order the first meeting with the mediator to the parties under $\S 100$, Para. 2, if practical and appropriate [§ 114c, Para. 3, lett c) and d) of CCP].

All of the above institutes relate to mediation and dispute resolution by settlement. However, the current legislation makes it possible to resolve the dispute out-of-court in a different way than by mediation in the course of the finding procedure. If the participants suggest it unanimously or if they fail to appear at the proceedings without a prior excuse, or if at least one of the participants suggests it and the others fail to appear to the proceedings without a prior excuse, the court shall adjourn the proceedings if this does not go against the purpose of the proceedings ( $\$ 110$ of CCP). If the proceedings are adjourned, the proceedings do not take place and the periods do not pass under CCP. If the proceedings continue, the periods start to pass again ( $\$ 111$, Para. 1 of CCP). If the proceedings are adjourned under $\S 110$, the court will continue based on a motion after expiry of a three-month period. The court can continue in the proceedings even before the expiry of this period if the reasons of this are grave enough. If the motion for the continuation of the proceedings is not made within one year, the court shall terminate the proceedings ( $\S 111$, Para. 3 of CCP). So-called rest in the proceedings therefore enables the participants to accept, for example, renegotiation. During the proceedings adjournment, the procedure periods are suspended, so are the limitation periods, and thusly space for the parties to make an agreement is created. The court continues in the proceeding only if the participants propose $\mathrm{so}^{17}$ and a potential settlement conclusion is not excluded under the agreement made by the participants in the meantime.

17 The proposal is not required if it is justified by the interests of a minor. 


\section{Limitation period}

Article 5 of the aforementioned Directive No. 2008/52/EC defines the optional recourse to mediation. A court before which an action is brought may, when appropriate and having regard to all the circumstances of the case, invite the parties to use mediation in order to settle the dispute. The court may also invite the parties to attend an information session on the use of mediation if such sessions are held and are easily available.

The Directive states in Article 8, point 1 that the Member States shall ensure that parties who choose mediation in an attempt to settle a dispute are not subsequently hindered from initiating judicial proceedings or arbitration in relation to that dispute by the expiry of the limitation period or statute of repose during the mediation process.

This regulation touches upon only one type of alternative dispute resolution: mediation. In the Czech Republic, this regulation was reflected in the Act on Mediation $^{18}$, the Civil Code ${ }^{19}$, and the Commercial Code ${ }^{20}$. After the new Civil Code (Act No. 89/2012 Coll., hereinafter referred to as NCC) coming into force, these regulations were incorporated into $\S 647$ of NCC and $\S 652$ of NCC in relation to all out-of-court negotiations. Under $\S 647$, in the event of making an agreement on out-of-court negotiations of the creditor and debitor about a right or circumstance on which the right is based, the limitation period starts passing after the creditor or debitor explicitly refuses to continue in such negotiations; if the limitation period started passing even before that, it is not passing during the negotiations. Under $\S$ 652 of NCC, if the passing of the limitation period continues after dropping of one of the obstructions stated in $\S 646$ to 651 , the limitation period terminates no sooner than six months from the day when it started passing again. ${ }^{21}$

$18 \S 29$ of the Act on Mediation in relation to mediation with a cross-border element and to mediations lead on the Czech Republic territory in $\S 32$ of Act on Mediation and $\S$ 33 of the Act on Mediation. § 404a of the Act No. 513/1991 Coll., Commercial Code. $\S 112, \S 583$, Para. 2 of the Act No. 40/1964 Coll., Civil Code.

$\S 404 \mathrm{a}$ of the Act No. 513/1991 Coll., Commercial Code.

21 Inspired by Art. III.-7:304 of the DCFR (2009) and $\S 203$ BGB: If negotiations between the obligor and the obligee are in progress in respect of the claim or the circumstances giving rise to the claim, the limitation period is suspended until one party or the other refuses to continue the negotiations. The claim is statute-barred at the earliest three months after the end of the suspension. The negotiations meaning in a broader sense, i.e. general exchange of opinions about the claim (see BGH, 2001). Refusal to continue meaning clear and unambiguous termination of negotiations (BGH, 1998). At the same time, the suspension ends at the instant when the parties' negotiations become dormant (BGH, 2008). 
In relation to all means of alternative dispute resolution, the passing of the limitation period is defined also in point 27 of the Recommendation. Under this point, any limitation period applicable to the claims should be suspended during the period from the moment the parties agree to attempt to resolve the dispute by means of an alternative dispute resolution procedure until at least the moment at which one or both parties expressly withdraw from that alternative dispute resolution procedure.

It is thus important to clear out what can be understood under the terms "the moment the parties agree to attempt to resolve the dispute by means of ADR", or "concluding the out-of-court negotiation agreement" which means the limitation period is suspended, as well as the terms "the moment at which one or both parties expressly withdraw from that alternative dispute resolution procedure" and this in relation to individual ways of alternative dispute resolution.

A. The creation of the obstruction for the passing of the limitation period causes suspension of the limitation period. In the case of so-called praetorian settlement, the moment of suspension of the limitation period is not identical to the moment of making a motion. ${ }^{22}$

The suspension of the limitation period under conciliation procedure occurs when the other party expresses a will to participate in an agreement. If the parties agreed before making the motion to start the conciliation procedure, the limitation period is suspended in this instant. Otherwise, it is suspended when the other party inform the court by a written statement that they are willing to try to reach conciliation or inform about this at ordered negotiations.

The termination of suspension of the limitation period occurs by legal force of the decision on conciliation approval. In such case, the limitation period is suspended and a new limitation period starts passing. Under $\S$ 640 of NCC, the right granted by a public authority decision is time-barred after ten years from the day when it should have been fulfilled under the decision.

The limitation period continues even sooner, by "the moment at which one or both parties expressly withdraw from that alternative dispute resolution procedure". In the case that both parties are present to the procedure and one of them states that they do not wish continue in the procedure,

22 For this cf. CCC, 1997: Such motion must meet the essentials stated in $\S 42$, Para. 4 of CCP, although this motion does not have substantive or procedural effects which the law otherwise connects with making a motion to start an action. 
the moment of the termination of suspension of the limitation period is apparent. However, if one of the parties is inactive, the court will no longer seek conciliation and the conciliation procedure will be terminated without issuance of the decision. Inactivity is not perceived as an explicit refusal of continuing in such a procedure. Contradictory interpretation would interfere with the legal certainty of both parties. The law and Recommendation require explicit ending of participation, that is, active conduct from one of the parties. The debitor will be always motivated to explicit refusal of further negotiations. In the case of the inactive debitor, the creditor has no reason to explicitly refuse. In such case, the limitation period is not passing.

If the limitation period continues to pass after dropping one of the obstructions in $\S 646$ to $\S 651$, the limitation period terminates no sooner than six months from the day it started to pass again.

The abovementioned cannot be applied to judicial settlements. Under $\S 648$ of NCC, if the creditor exercises the right by a public authority during the limitation period and he/she continues properly in the initiated proceedings, the limitation period is not passing.

B. Concerning mediation, the aforementioned moments of suspension of the limitation period mean the conclusion of the mediation agreement under $\S 4$ of the Act on Mediation. The suspension of the limitation period is terminated when the participants refuse to continue in mediation negotiations; the limitation period continues passing from this moment on but ends no sooner than six months from the day it is started passing again ( $\$ 652$ of NCC). If the parties make a mediation agreement, a new legal relationship is created that causes a new limitation period to pass.

C. Contrary to the aforementioned case, it is not difficult to determine the moment of suspension of the limitation period, nor the moment of its termination in the case of the initiation of arbitration. Under $\S 3017$ of NCC, the regulations of this act which relate to exercising the right before the court or in judicial procedure or ruling of the court are similarly used for exercising the right before the arbitrator, arbitration or arbitral award as well. In theory, an earlier moment of suspension of the limitation period could be considered, this being the instant when the parties agree on resolving the dispute before the arbitrator. Should the parties make an arbitration clause, the start of the limitation period would not occur, suspension of the limitation period would take place in the case of agreement on arbitrator. 
However, we think that, with regard to legal certainty and purpose under $\S 647$ of NCC, this interpretation is not possible. The termination of suspension occurs by legal force of the arbitral award (a new limitation period starts passing after that under $\S 640$ of NCC) or decision which terminated the arbitration (the original limitation period will continue by legal force of this decision, for specifications of the effects of procedure initiations cf. $\S 16$ of the Act on Arbitration), unless it was terminated because the claimant did not continue the procedure properly.

\section{Legality verification by court}

The legality of the binding outcome of a collective settlement should be verified by the courts taking into consideration the appropriate protection of interests and rights of all the parties involved (point 28 of the Recommendation). Even though the Czech translation uses the term kolektivni smir, which is connected to $\S 67$ et seq. of CCP and $\S 99$ of CCP in our approach, the English original uses the term collective settlement. It is therefore any form of dispute resolution by agreement.

The said regulation can be interpreted in three ways. First, the most similar to the Czech legal order, is that the participants of this agreement must be given an option to have this agreement validated by the court, so that it can become an enforcement order (Art. 6 of the Directive 2008/52/EC). Czech legislation on the so-called praetorian settlement under $\S 67$ et seq. of CCP makes this possible. Such a resolution is most effective for dispute parties also with regard to the fact that the settlement validated by the court has effect on the final judgement ( $§ 99$, Para. 3 of CCP). The current legislation explicitly defines the validation of the mediation agreement with the simultaneous determination of the maximum period of 30 days from the initiation of the conciliation procedure ( $\$ 67$, Para. 2 of CCP).

The second alternative is that the Member States should ensure that the dispute resolution agreement could be a subject matter of procedure on its validity or invalidity, even without the claimant party having to prove an urgent legal interest which is otherwise required by an action on declaratory judgement for the claimant to be successful ( $\$ 80$ of CCP) Similarly in the Czech legal environment, the legislation covers, for example, the option to claim invalidity of termination of employment which can be done by agreement with both the employer and employee, in court no later than two months from the day when the employment should have been terminated ( $\$ 72$ of the Act No. 262/2006 Coll., 
Labour Code). The law, however, makes it possible to demand the invalidity of this agreement only.

The last possible interpretation is that the validation of this agreement by the court is obligatory for its coming into force. Though we believe that such an interpretation is inappropriate with respect to the costs of such proceedings and swiftness of the resolution.

In the case of an arbitral award, it is already an enforceable decision and validation by the court is not necessary. The court can annul the arbitral award in exceptional cases ( $\$ 31$ et seq. of the Arbitration Code).

\section{Conclusion}

The Recommendation of the Commission on common principles for injunctive and compensatory collective redress mechanisms set the framework for the future legislation on collective court or out-of-court redress. As we stated in the article, the current legislation on alternative dispute resolution in the Czech Republic provides sufficient options for resolving legal disputes without judicial engagement, or without the need to initiate the finding procedure. The parties to legal relations are encouraged by the legal order to use these means, both before the start of the legal proceedings (cf. legislation on statute of limitations) and during its progress.

Any of the alternative dispute resolution forms do not exclude the application of the principles of the Recommendation, however necessary it would be to take into consideration specifics of some of the forms of ADR (e.g., informality of mediation or arbitration proceedings being non-public) of some of these forms during their implementation.

The task that we consider primary for the Czech legislature is to create general collective redress legislation. Two options come into consideration ${ }^{23}$ : a separate lex specialis on collective legal proceedings with subsidiary application of the CCP (Balarin \& Tichý, 2013, pp. 17-26), or implementation of the new legislation directly into the existing CCP or into a new civil procedure law codification which is currently in the state of preparations.

23 In relation to claim for ceasing of certain act, the representative and group model come into consideration. On the contrary, in relation to actions for redress the group system would be more appropriate - opt-in, with regards to lesser difficulty when deciding on awarding redress. 
During June 2016, a legislative committee was summoned to prepare a legislation on group actions; ${ }^{24}$ this was initiated by members of the legislative committee that prepares the new civil procedure law codification. During the debates, all the options mentioned above were thoroughly discussed. However, the conceptual issue remains unresolved for the time being.

From the point of view of legislation and application, it would be more appropriate, in our opinion (especially with respect to suitability of reflection of the new principles which the new civil procedure law codification in progress will based on, and its new terminology in legislation on of collective legal protection), for the legislation on collective legal protection to be developed simultaneously (whether under one committee or in parallel). Therefore it is possible to support the direct implementation of special provisions into the new civil procedure law codification, for example, in a form of a special chapter of this legal document with subsidiary application of general legislation on legal proceedings.

The choice of a specific option, however, depends primarily on the time scale of creating the new civil procedure law codification (it can be assumed that this means several years). The Czech government can, however, reach a conclusion that it is necessary to reflect the principles of the Commission's Recommendation in the Czech legal order as soon as possible. This could be accomplished by an amendment of the existing Civil Procedure Code or by the very separate law on collective protection of rights. Such a law would necessarily require to incorporate a compact legislation on proceedings without the necessity of subsidiary application of the Civil Procedure Code because otherwise it would require a substantial novelisation after adopting the new civil procedure law codification. ${ }^{25}$ Again, such legislative process would presumably be lengthy. In the case of a legislatively more economical (meaning more concise) law with subsidiary application of the Civil Procedure Code, almost no interventions would be necessary in consequence, however, with regards to the state of the existing Civil Procedure Code ${ }^{26}$, this option is conditioned by its current amendment.

With regards to the mentioned absence of legislation on collective court proceedings, it can be assumed that the legislature will firstly focus thoroughly

24 Authors are members of this committee.

25 A certain option, of course, would be implementing the collective protection of rights into the new codification, and its coming into force would abolish the lex specialis on collection protection of rights.

26 More on this see above in the article. 
and primarily on this field. Together with resolving this deficiency in legislation, however, it will be necessary to consider how the concept of the new legislation will reflect in the legislation of means of alternative dispute resolution. We believe that it will suffice to add the specifics mentioned above in this article or the limited possibilities to reflect the principles of the Recommendation in the legislation of alternative dispute resolution to special legislation on alternative dispute resolution (e.g., arbitration proceedings) with subsidiary application of general legislation on collective protection of rights. The exception will be the necessity to consider the informal nature of mediation, and therefore the existing Act on Mediation should be amended with a completely special legislation.

JUDr. Klára Hamul'áková, PhD is senior lecturer at the Department of Private Law and Civil Procedure of Faculty of Law at Palacký University Olomouc. She has a PhD in civil law (civil procedural law). The topic of her $\mathrm{PhD}$ work is 'Legal regulation of judicial control of administrative bodies in private matters'. She is also assistant to Justice at Constitutional Court. Her research interests include civil procedural law, civil law and administrative law.

JUDr. Jana Petrov Křiváčková, PhD is senior lecturer at the Department of Private Law and Civil Procedure of Faculty of Law at Palacký University Olomouc. She has a PhD in civil law (civil procedural law) from Palacký University in Olomouc. She is also assistant to Justice at Constitutional Court. Her research interests include civil procedural law, civil law and constitutional law.

\section{References}

Act on Mediation (Czech Republic), Act No. 2002/2012 Coll.

Act on Takeover Bids (Czech Republic), Act. No. 104/2008 Coll.

Balarin, J. \& Tichý, L. (2013), 'Kolektivní ochrana procesních práv v ČR: sen či skutečnost? (návrh právní úpravy a jeho odůvodnění)' [The Collective redress of procedural rights in Czech Republic: Dream or reality?)], Bulletin advokacie [Bulletin of Advocacy], vol. 17, no. 3, pp. 17-26.

Bělohlávek, A. J. (2012), Zákon o rozhodčím řizení a o výkonu rozhodčích nálezů: Komentár $r 2^{\text {nd }}$ edition (Act on Arbitration Proceedings and Enforcement of Arbitral Awards: The Commentary), Prague: C. H. Beck.

BGH (1998), German Bundesgerichtshof decision, VI ZR 260/97, 30 June 1998.

— (2001), German Bundesgerichtshof decision, VI ZR 208/00, 8 May 2001.

(2008), German Bundesgerichtshof decision, IX ZR 158/07, 6 November 2008.

CCC (1997), Czech Constitutional Court decision, III. ÚS 144/97, 2 June 1997. 
— (2011), Czech Constitutional Court decision, I. ÚS 3227/07, 8 March 2011.

Civil Code (Czech Republic), Act No. 40/1964 Coll., Act No. 89/2012 Coll.

Code of Civil Procedure (Czech Republic), Act No. 99/1963 Coll.

Commercial Code (Czech Republic), Act No. 513/1991 Coll.

Consumer Protection Act (Czech Republic), Act. No. 634/1992 Coll.

CSC (2012), Czech Supreme Court resolution, 20 Cdo 2487/2010, 16 August 2012.

DCFR (2009), Study Group on European Civil Code and Research Group on EC Private

Law. Principles, Definitions and Model Rules of European Private Law: Draft

Common Frame of Reference Retrieved from http://ec.europa.eu/justice/policies/ civil/docs/dcfr_outline_edition_en.pdf [accessed 9 Sep 2015]

EC = European Commission (2001), 'Towards a Coherent European Approach to Collective Redress,' Commission Public Consultation, SEC (2011) 173 final, 4.2.2011.

(2004), Regulation of the European Parliament and of the Council 2006/2004 on cooperation between national authorities responsible for the enforcement of consumer protection laws (the Regulation on consumer protection cooperation), Official Journal of the European Union, L 364, 9.12.2004, pp. 1-11.

- (2005), Commission Green Paper Damages Actions for Breach of the EC Antitrust Rules, SEC(2005) 1732, 19.12.2005, COM (2005) 672.

(2008a), Commission Green Paper on Consumer Collective Redress, COM(2008) 794 final, 27.11.2008.

- (2008b), Commission White Paper on damages actions for breach of the EC antitrust rules, SEC(2008) 404, SEC(2008) 405, SEC(2008) 406, 2.4.2008, COM (2008) 165.

(2008c), Directive of the European Parliament and of the Council 2008/52/EC on certain aspects of mediation in civil and commercial matters, Official Journal of the European Union, L 136, 24.5.2008, pp. 3-8.

(2009), Directive of the European Parliament and of the Council 2009/22/EC on injunctions for the protection of consumers' interests Official Journal of the European Union, L 110, 1.5.2009, pp. 30-36.

(2013a), 'Towards a European Horizontal Framework for Collective Redress,' Communication from the Commission to the European Parliament, the Council, the European Economic and Social Committee and the Committee of the Regions, COM(2013) 401 final, 11.6.2013.

(2013b), Recommendation of Commission 2013/396/EU on common principles for injunctive and compensatory collective redress mechanisms in the Member States concerning the violations of rights granted under Union Law, Official Journal of the European Union, L 201, 26.7.2013, pp. 60-65.

European Commission - DG Sanco (2008), Evaluation of the Effectiveness and Efficiency of Collective Redress Mechanisms in the European Union, Civic Consulting (Lead) 
and Oxford Economics. Retrieved from http://ec.europa.eu/consumers/archive/ redress_cons/finalreportevaluationstudypart1-final2008-11-26.pdf [accessed 9 Sep 2015]

Freer, R. D. (2012), Civil Procedure, $3^{\text {rd }}$ edition, Aspen: Wolters Kluwer.

Notarial Code (Czech Republic), Act No. 358/1992 Coll. 